\title{
EXPERIMENTAL INFECTION OF CALVES, PIGLETS AND LAMBS WITH MIXTURES OF INVASIVE AND ENTEROPATHOGENIC STRAINS OF ESCHERICHIA COLI
}

\author{
H. Williams Smith and M. B. Huggins
}

Houghton Poultry Research Station, Houghton, Huntingdon, Cambs. PE17 2DA

AT LEAST two kinds of Escherichia coli cause disease in young domestic mammals. Strains of the invasive kind produce generalised infections, principally in immunoglobulin deficient (IG-) animals that have obtained inadequate colostrum soon after birth. Strains of the enteropathogenic kind produce diarrhoea, often in animals that have substantial levels of immunoglobulins in their blood. Generalised $E$. coli infections can be produced by giving IG - animals invasive strains orally. The organisms invade the body and multiply in the tissues, where they are found in high concentrations when the animals are near death; animals that have adequate immunoglobulins in their blood $(\mathrm{IG}+)$ remain well after the oral administration of these strains, the organisms being confined to the alimentary tract and its associated lymph glands (Smith and Halls, 1968b). In contrast to the invasive strains, enteropathogenic strains given orally do not usually invade the bodies of IG + or IG - animals; they may, of course, proliferate and reach very high numbers in the small intestine (Smith and Halls, 1967; Smith and Huggins, 1978). To obtain comparative information on the distribution of invasive and enteropathogenic strains in experimentally infected animals, mixed infections were set up in IG - and IG + calves, lambs and piglets with an invasive strain, an enteropathogenic strain and a non-pathogenic strain of $E$. coli; the results are reported in this paper. The feasibility of this approach, which reduces the effect of genetic and other variations that exist between individual animals of the same species, has been demonstrated in a related investigation (Smith and Huggins, 1978).

\section{MATERIALS AND METHODS}

Strains of E. coli. An enteropathogenic O9:K30,99 strain (EP) was isolated from the small intestine of a calf with diarrhoea; it produced heat-labile (LT) and heat-stable (ST) enterotoxin (Smith and Gyles, 1970). An invasive $\mathrm{O} 78: \mathrm{H}^{-}$strain (IN) was isolated from the heart blood of a calf with generalised $E$. coli infection; it possessed the pathogenic colicine V plasmid (Smith and Huggins, 1976). Spontaneous chromosomal mutants resistant to ampicillin (EP strain) and rifampicin (IN strain) were prepared (Smith and Huggins, 1978) for the infection experiments described here. The non-pathogenic strain (NP) had been isolated from the faeces of a healthy pig; it was a naturally occurring mutant resistant to tetracyclines and could not be typed. The three mutant strains were grown in 10-ml volumes of Nutrient Broth No. 2 (Oxoid) for $24 \mathrm{~h}$ in a shaking water bath at $37^{\circ} \mathrm{C}$; these cultures contained approximately $10^{9}$ viable organisms per ml.

Experimental animals. The calves were from a Jersey herd, the lambs from a Suffolk flock and the piglets from a Large White herd. All animals classed as IG - were removed from their mothers as soon as they were born. Those classed as IG + were left with their mothers for up to $6 \mathrm{~h}$ during which time they had consumed a substantial amount of colostrum. The IG status of all animals was confirmed by the zinc-sulphate flocculation test (Aschaffenburg, 1949); the sera of the three animals classed as IG - gave a completely negative reading in the test and those from the animals classed as IG + gave a good positive reading. The animals were fed on heat-sterilised cows' milk given by stomach tube; the calves received 1 litre three times daily, the lambs 300 $\mathrm{ml}$ three times daily and the piglets $40-60 \mathrm{ml}$ five times daily.

Received 22 Dec. 1978; accepted 28 Mar. 1979.

J. MED. MICROBIOL.--VOL. 12 (1979) 
Inoculation and subsequent examination of experimental animals. Calves were inoculated orally with $10^{9}$ viable organisms of each of the three strains of $E$. coli, and lambs and piglets with $10^{7}$ organisms; all animals were inoculated within $12 \mathrm{~h}$ of birth. The animals were inspected at frequent intervals and, if death appeared imminent, they were killed by parenteral injection of sodium pentobarbitone. Otherwise, they were killed $24-28 \mathrm{~h}$ after inoculation. Immediately after death, the concentrations of viable organisms of the inoculated $E$. coli strains in the different parts of the alimentary tract were estimated by the method of Smith and Halls (1968a); those in the tissues were estimated by the method of Smith and Halls (1968b). All bacterial counts were performed on three sets of plates of MacConkey's agar, each set containing either rifampicin $100 \mu \mathrm{g} / \mathrm{ml}$ (for IN organisms), or ampicillin $20 \mu \mathrm{g} / \mathrm{ml}$ (for EP organisms), or tetracycline $20 \mu \mathrm{g} / \mathrm{ml}$ (for NP organisms), so that the numbers of organisms of each of the three inoculated strains in each specimen could be estimated. A fourth set containing MacConkey's agar without added antibiotics was included to detect 'contaminating' $E$. coli organisms present in high concentrations-none was found.

\section{RESULTS AND DISCUSSION}

The results of estimating the concentration of the invasive (IN), enteropathogenic (EP) and non-pathogenic (NP) strains in the alimentary tract and in the tissues of an IG - and an IG + calf, lamb and piglet that had been inoculated orally with a mixture of these three strains are summarised in tables I and II. The IG - calf, lamb and piglet were killed 17, 20 and $19 \mathrm{~h}$ respectively after inoculation when they were near death; all had had severe diarrhoea. The IG + calf, lamb and piglet were killed 26,24 and $24 \mathrm{~h}$ respectively after inoculation when the calf had severe diarrhoea, the piglet had moderately severe diarrhoea and the lamb was normal. High concentrations of organisms of the EP strain and much lower concentrations of organisms of the IN and NP strains were found in the small intestine and colon of the IG - calf, lamb and piglet (table I), the concentrations of the NP strain being considerably lower than those of the IN strain in the posterior small intestine and colon of the calf and piglet. High concentrations of organisms of the IN strain were found in the liver, spleen, kidney and heart blood of all three IG - animals. Organisms of the other two strains were either present in these sites in very low

\section{TABLE I}

The number of organisms in the alimentary tract and in the tissues of an immunoglobulin-deficient calf, lamb and piglet that had been given a mixture of three different Escherichia coli strains orally*

\begin{tabular}{|c|c|c|c|c|c|c|c|c|c|c|c|c|}
\hline \multirow[b]{3}{*}{ Animal } & \multirow{3}{*}{$\begin{array}{c}\text { E. coli } \\
\text { strains } \\
\text { in mixture* }\end{array}$} & \multicolumn{11}{|c|}{ Number of organisms $\left(\log _{10}\right.$ per $\left.g\right)$ in } \\
\hline & & \multirow[b]{2}{*}{ stomach } & \multicolumn{4}{|c|}{ small intestine, part $\dagger$} & \multirow[b]{2}{*}{ colon } & \multirow{2}{*}{$\begin{array}{c}\text { mesenteric } \\
\text { lymph gland } \ddagger\end{array}$} & \multirow[b]{2}{*}{ liver } & \multirow[b]{2}{*}{ spleen } & \multirow[b]{2}{*}{ kidney } & \multirow[b]{2}{*}{ blood } \\
\hline & & & 1 & 3 & 5 & 7 & & & & & & \\
\hline Calf & $\begin{array}{l}\text { IN } \\
\text { EP } \\
\text { NP }\end{array}$ & $\begin{array}{l}7.0 \\
6.6 \\
6.5\end{array}$ & $\begin{array}{l}6 \cdot 5 \\
6 \cdot 4 \\
6 \cdot 3\end{array}$ & $\begin{array}{l}7 \cdot 3 \\
9 \cdot 7 \\
6 \cdot 3\end{array}$ & $\begin{array}{l}6.9 \\
9 \cdot 8 \\
4 \cdot 7\end{array}$ & $\begin{array}{l}6 \cdot 0 \\
9.9 \\
4.7\end{array}$ & $\begin{array}{l}6.9 \\
9.9 \\
5 \cdot 3\end{array}$ & $\begin{array}{l}5.4 \\
4 \cdot 6 \\
2 \cdot 0\end{array}$ & $\begin{array}{r}5.8 \\
2.0 \\
<2.0\end{array}$ & $\begin{array}{r}6.0 \\
<2.0 \\
2.5\end{array}$ & $\begin{array}{r}7.0 \\
2.0 \\
<2.0\end{array}$ & $\begin{array}{r}5.0 \\
<2.0 \\
<2.0\end{array}$ \\
\hline Lamb & $\begin{array}{l}\text { IN } \\
\text { EP } \\
\text { NP }\end{array}$ & $\begin{array}{l}7 \cdot 3 \\
7 \cdot 3 \\
7 \cdot 3\end{array}$ & $\begin{array}{l}4 \cdot 5 \\
9 \cdot 3 \\
3 \cdot 3\end{array}$ & $\begin{array}{l}4 \cdot 0 \\
9 \cdot 3 \\
3 \cdot 8\end{array}$ & $\begin{array}{l}4 \cdot 3 \\
9 \cdot 6 \\
4 \cdot 0\end{array}$ & $\begin{array}{l}5 \cdot 3 \\
9 \cdot 7 \\
4 \cdot 9\end{array}$ & $\begin{array}{l}5 \cdot 5 \\
9 \cdot 5 \\
5 \cdot 3\end{array}$ & $\begin{array}{l}6 \cdot 0 \\
4 \cdot 8 \\
2 \cdot 5\end{array}$ & $\begin{array}{r}8 \cdot 2 \\
<2 \cdot 0 \\
<2 \cdot 0\end{array}$ & $\begin{array}{l}7 \cdot 6 \\
3 \cdot 7 \\
3 \cdot 3\end{array}$ & $\begin{array}{r}7.9 \\
<2.0 \\
<2.0\end{array}$ & $\begin{array}{r}8 \cdot 3 \\
3 \cdot 5 \\
<2 \cdot 0\end{array}$ \\
\hline Piglet & $\begin{array}{l}\text { IN } \\
\text { EP } \\
\text { NP }\end{array}$ & $\begin{array}{l}6 \cdot 7 \\
6 \cdot 8 \\
6 \cdot 8\end{array}$ & $\begin{array}{l}6 \cdot 7 \\
7 \cdot 3 \\
7.0\end{array}$ & $\begin{array}{l}7 \cdot 0 \\
7 \cdot 3 \\
7 \cdot 3\end{array}$ & $\begin{array}{l}6 \cdot 7 \\
9 \cdot 8 \\
5 \cdot 3\end{array}$ & $\begin{array}{r}7 \cdot 3 \\
10 \cdot 0 \\
5 \cdot 5\end{array}$ & $\begin{array}{l}7 \cdot 3 \\
9 \cdot 5 \\
6 \cdot 3\end{array}$ & $\begin{array}{r}4.5 \\
4.5 \\
<2.0\end{array}$ & $\begin{array}{r}6.7 \\
2.0 \\
<2.0\end{array}$ & $\begin{array}{r}6.3 \\
<2.0 \\
<2.0\end{array}$ & $\begin{array}{r}6.7 \\
<2.0 \\
<2.0\end{array}$ & $\begin{array}{r}7.0 \\
<2.0 \\
<2.0\end{array}$ \\
\hline
\end{tabular}

\footnotetext{
* The calf was given a mixture of $10^{9}$ viable organisms of each of the three strains and the lamb and piglet $10^{7}$ of each of them; IN = invasive strain, EP= enteropathogenic strain, and NP= non-pathogenic strain. $\dagger$ The small intestine was divided into seven equal parts for counting; part 1 was nearest the stomach and part 7 nearest the colon.

$\ddagger$ The figure for the mesenteric lymph gland is the median of the results three glands.
} 
TABLE II

The number of organisms in the alimentary tract and in the tissues of an $I G+$ calf, lamb and piglet that had been given a mixture of three different $E$. coli strains orally*

\begin{tabular}{|c|c|c|c|c|c|c|c|c|c|c|c|c|}
\hline \multirow[b]{3}{*}{ Animal } & \multirow{3}{*}{$\begin{array}{l}E \text {. coli } \text { strains } \\
\text { in mixture* }\end{array}$} & \multicolumn{11}{|c|}{ Number of organisms $\left(\log _{10}\right.$ per $\left.g\right)$ in } \\
\hline & & \multirow[b]{2}{*}{ stomach } & \multicolumn{4}{|c|}{ small intestine, part $\dagger$} & \multirow[b]{2}{*}{ colon } & \multirow{2}{*}{$\begin{array}{c}\text { mesenteric } \\
\text { lymph gland } \ddagger\end{array}$} & \multirow[b]{2}{*}{ liver } & \multirow[b]{2}{*}{ spleen } & \multirow[b]{2}{*}{ kidney } & \multirow[b]{2}{*}{ blood } \\
\hline & & & 1 & 3 & 5 & 7 & & & & & & \\
\hline Calf & $\begin{array}{l}\text { IN } \\
\text { EP } \\
\text { NP }\end{array}$ & $\begin{array}{l}5 \cdot 3 \\
5 \cdot 6 \\
5 \cdot 3\end{array}$ & $\begin{array}{l}5 \cdot 5 \\
9 \cdot 8 \\
5 \cdot 3\end{array}$ & $\begin{array}{l}5.9 \\
9 \cdot 8 \\
5 \cdot 0\end{array}$ & $\begin{array}{r}6 \cdot 0 \\
10 \cdot 2 \\
5 \cdot 0\end{array}$ & $\begin{array}{r}6.0 \\
10.0 \\
4.9\end{array}$ & $\begin{array}{r}6 \cdot 0 \\
10 \cdot 2 \\
5 \cdot 5\end{array}$ & $\begin{array}{l}3 \cdot 5 \\
6 \cdot 2 \\
2 \cdot 0\end{array}$ & $\begin{array}{l}<2 \cdot 0 \\
<2 \cdot 0 \\
<2 \cdot 0\end{array}$ & $\begin{array}{l}<2 \cdot 0 \\
<2 \cdot 0 \\
<2 \cdot 0\end{array}$ & $\begin{array}{l}<2 \cdot 0 \\
<2 \cdot 0 \\
<2 \cdot 0\end{array}$ & $\begin{array}{l}<2.0 \\
<2.0 \\
<2.0\end{array}$ \\
\hline Lamb & $\begin{array}{l}\text { IN } \\
\text { EP } \\
\text { NP }\end{array}$ & $\begin{array}{l}5 \cdot 3 \\
4 \cdot 3 \\
4 \cdot 7\end{array}$ & $\begin{array}{l}5 \cdot 0 \\
4 \cdot 5 \\
5 \cdot 0\end{array}$ & $\begin{array}{l}6 \cdot 0 \\
5 \cdot 5 \\
5 \cdot 8\end{array}$ & $\begin{array}{l}6 \cdot 2 \\
5 \cdot 2 \\
6 \cdot 3\end{array}$ & $\begin{array}{l}7 \cdot 5 \\
7 \cdot 3 \\
5 \cdot 7\end{array}$ & $\begin{array}{l}8 \cdot 0 \\
9 \cdot 3 \\
6 \cdot 3\end{array}$ & $\begin{array}{r}<2.0 \\
2.0 \\
<2.0\end{array}$ & $\begin{array}{l}<2.0 \\
<2.0 \\
<2.0\end{array}$ & $\begin{array}{l}<2.0 \\
<2.0 \\
<2.0\end{array}$ & $\begin{array}{l}<2.0 \\
<2.0 \\
<2.0\end{array}$ & $\begin{array}{l}<2.0 \\
<2.0 \\
<2.0\end{array}$ \\
\hline Piglet & $\begin{array}{l}\text { IN } \\
\text { EP } \\
\text { NP }\end{array}$ & $\begin{array}{l}5 \cdot 0 \\
5 \cdot 0 \\
4 \cdot 5\end{array}$ & $\begin{array}{l}4 \cdot 7 \\
4 \cdot 6 \\
4 \cdot 4\end{array}$ & $\begin{array}{l}6 \cdot 3 \\
5 \cdot 5 \\
5 \cdot 6\end{array}$ & $\begin{array}{l}6 \cdot 8 \\
6 \cdot 0 \\
5 \cdot 8\end{array}$ & $\begin{array}{l}6 \cdot 7 \\
8.9 \\
5 \cdot 0\end{array}$ & $\begin{array}{l}6.7 \\
7.6 \\
3.9\end{array}$ & $\begin{array}{r}<2.0 \\
2.6 \\
<2.0\end{array}$ & $\begin{array}{l}<2 \cdot 0 \\
<2 \cdot 0 \\
<2 \cdot 0\end{array}$ & $\begin{array}{l}<2.0 \\
<2.0 \\
<2.0\end{array}$ & $\begin{array}{l}<2.0 \\
<2.0 \\
<2.0\end{array}$ & $\begin{array}{l}<2.0 \\
<2.0 \\
<2.0\end{array}$ \\
\hline
\end{tabular}

Footnotes as in table I.

concentrations or, more usually, were not found at all. The concentrations of organisms of the EP strain in the mesenteric lymph glands were higher than those of organisms of the NP strain, approaching those of organisms of the IN strain.

Much higher concentrations of organisms of the EP strain than of organisms of the other strains were present in the small intestine of the IG + calf and in the lower part of the small intestine of the IG + piglet (table II); the absence of a corresponding proliferation of the EP strain in the lamb might well have been due to the presence of antibody to this strain in the colostrum it had received. The concentrations of organisms of the other two strains in the small intestine in all three animals were relatively low; in general, the concentration of organisms of the IN strain present were little higher than those of the NP strain. No organisms of either strain were found in the liver, spleen, kidney or heart blood of the three IG + animals. The EP strain was present in the mesenteric lymph glands of all three, in moderately high concentrations in the calf and in low concentrations in the lamb and piglet; low concentrations of the other two strains were also found in the mesenteric lymph glands of the calf but not of the lamb and piglet.

Although the differences we have observed might have been less with other strains, our mixed-infection studies have emphasised the important ecological differences between enteropathogenic and invasive strains of $E$. coli. The EP strain was able to proliferate in the small intestines of IG - and IG + animals but not in their tissues, whilst the IN strain proliferated in the tissues of IG - animals but did not reach such high numbers as the EP strain in the small intestine. It is noteworthy in this respect that the concentrations of the EP strain in the tissues of the experimental animals and of the IN strain in their small intestines were usually little higher than those of the NP strain in those sites.

\section{SUMMARY}

Mixtures of mutant organisms of an invasive (IN) strain, a strain enteropathogenic (EP) for calves, lambs and piglets, and a non-pathogenic (NP) strain of Escherichia coli, that could be differentiated from each other by their antibiotic resistances, were given orally to an immunoglobulin-negative $(I G-)$ and an immunoglobulin-positive $(I G+)$ calf, lamb and piglet. By the use of appropriate antibiotic-containing culture media, the concentrations of organisms of each of the three strains in the contents of the alimentary tracts and tissues (liver, spleen, kidney, blood and mesenteric lymph glands) of the animals were estimated when they were killed. In the three IG - animals, the IN strain proliferated in the tissues and the EP strain proliferated in the small intestines; in general, the concentrations of the IN strain in the small intestines and the EP strain 
in the tissues, apart from the mesenteric lymph glands, were as low as those of the NP strain in these sites. The only strain that proliferated in the small intestine of the IG + animals was the EP strain, which proliferated in the small intestine of the calf and piglet; no organisms of either strain were isolated from the tissues of these three animals, except from their mesenteric lymph glands.

We are grateful to Mrs Frances Richards and Mr David Moon for their capable technical help. Our thanks are also due to Dr P. M. Biggs, Mrs Wendy Bruce, Dr B. Rowe and Miss Susan Shaw for help and assistance in a variety of ways.

\section{REFERENCES}

ASChaffenburg, R. 1949. The nutritive value of colostrum for the calf. 3. Changes in the serum protein of the newborn calf following the ingestion of small quantities of the non-fatty fraction. Br.J. Nutr., 3, 200.

SMITH, H. Williams AND Gyles, C. L. 1970. The relationship between two apparently different enterotoxins produced by enteropathogenic strains of Escherichia coli of porcine origin. $J$. med. Microbiol., 3, 387.

Smith, H. Williams and Halls, Sheila. 1967. Observations by the ligated intestinal segment and oral inoculation methods on Escherichia coli infections in pigs, calves, lambs and rabbits. J. Path. Bact., 93, 499.

Smith, H. Williams and Halls, Sheila. 1968a. The production of oedema disease and diarrhoea in weaned pigs by the oral administration of Escherichia coli: factors that influence the course of the experimental disease. J. med. Microbiol., 1, 45.

Smith, H. Williams and Halls, Sheila. 1968b. The experimental infection of calves with bacteriaemia-producing strains of Escherichia coli: the influence of colostrum. J. med. Microbiol., 1, 61.

Smith, H. Williams ANd Huggins, M. B. 1976. Further observations on the association of the colicine $\mathrm{V}$ plasmid of Escherichia coli with pathogenicity and with survival in the alimentary tract. J. gen. Microbiol., 92, 335.

Smith, H. Williams AND HugGins, M. B. 1978. The influence of plasmid-determined and other characteristics of enteropathogenic Escherichia coli on their ability to proliferate in the alimentary tract of piglets, calves and lambs. J. med. Microbiol., 11, 471. 